\title{
透明レプリカ法による加工表面の粗さ測定方法の提案*
}

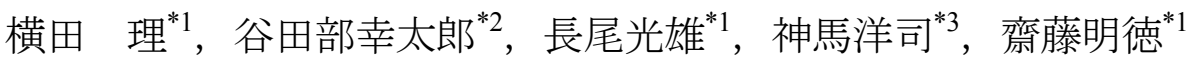

\section{The Proposal of Measuring Method of Machined Surface Roughness Using Transparent Replica}

\author{
Osamu YOKOTA* ${ }^{* 1}$, Kotaro YATABE, Mitsuo NAGAO, Yoji JIMBA and Akinori SAITO \\ ${ }^{* 1}$ Department of Mechanical Engineering, College of Engineering, Nihon University \\ 1 Nakakawahara, Tokusada, Tamura-machi, Koriyama-shi, Fukushima, 963-8642, Japan
}

In this study, the replica of the metal processing surface was produced using the transparent silicone. The new measuring method which examined the transmission image was proposed with a scattering of the spot light in the replica. The result was summarized in the following. It was able to be classified to four patterns of the transmission image from the replica reflection plane, that is to say, point pattern, circular pattern, elliptic pattern, diffractionpattern. It is possible that these patterns estimate the shape of the reflection plane, namely shape and processing method of the machined surface. The surface roughness by the diffraction was equal to the maximum height roughness by the tracer. In circular pattern and elliptic pattern, the empirical formula which showed the relationship between maximum height roughness and radius of gyration was obtained. In the point pattern, it was not possible to show surface roughness in the measuring range of this experiment.

Key Words : Surface Roughness, Arithmetic Mean Roughness, Shape Measurement, Laser Measurement, Electrical Discharge Machining, Chaos and Fractal, Image Processing

\section{1. 緒言}

素材や部品は切削，研削，研磨などの加工により所望の寸法に仕上げられるが，それらの加工表面は，完成し た機械の性能や外観に影響を及ぼすので，ますます高い加工精度が要求される ${ }^{(1)}$. 現在の測定技術の多くは，凹 凸の規模を粗さとして測定するものであり，主な測定方法(2),(3) としては，加工表面への触針による接触式粗さ測 定法，光干涉や光切断を利用した非接触式粗さ測定法がある. 触針による接触式粗さ測定法は，針が加工表面に かける圧力によって測定精度が変化し, 比較的高い圧力をかけた場合には測定精度が高まる傾向にある.しかし, 圧力によっては表面が傷つき，正確な粗さを測定できないおそれがあり，また複数回の計測を必要とするので， 計測時間がかかるという久点がある. 光切断を利用した粗さ測定法は，照射するスリット光の投影方法によって はマイクロメートル程度まで表面粗さを測定することが可能である.しかし，この測定方法は，スリット光の投 影角度によって測定精度が変化するため，十分な信頼性のある測定值が得られない場合がある．さらに，光干渉 を利用した粗さ測定法は，測定の対象となる表面粗さが 1 マイクロメートル以下でも計測できるが，反射率は比 較的高い部材であることが望ましい.

一方，加工表面に直接照射された光線の反射光強度は表面粗さが大きくなるほど広がるので，その散乱光の広 がりから表面粗さを評価する光散乱法(4) (8)がある.これに関する報告は数多くある．粗さ測定にあたつては，加 工表面を直接測定するのではなく，加工表面の凹凸を再現したレプリカを利用することがある. この法はレプ

\footnotetext{
* 原稿受付 2011 年 11 月 2 日

*1 正員，日本大学工学部機械工学科（广963-8642＼cjkstart福島県郡山市田村町徳定字中河原 1 番地）

*2 日本大学大学院工学研究科機械工学専攻

*3 日本大学工学部総合教育

E-mail: yokota@mech.ce.nihon-u.ac.jp
} 
リカ測定法(9),(10) と呼ばれ，構造物や大型部品の表面のレプリカを採取して，そのレプリカ表面に光を照射，反射 させたときの光量を測定して粗さを表示寸る．しかし，光を透明レプリカに照射させ，その反映面からの透過光 の状態を粗さ測定に用いた報告は見当たらない. 従来のレプリカ測定法は，反射光を利用しているために反射像 の歪みによる補正が必要になること，また複数の反射ミラーを用いるので計測部品が数点多くなることなどが挙 げられる，一方，透明レプリカ法は，レプリカ反映面の背面は平坦であるので透過光の歪みは現れにくく, 装置 もコンパクトになる利点がある.

本研究では，透明レプリカによる粗さ測定方法(11)を提案する．本測定法は，透明シリコーンを用いて様々な凹 凸のある加工表面のレプリカを作製し，レプリカの凹凸面を反映面とし，反映面と反対に位置する面を背面とす る. 背面は凸凹のない面である，レプリカの背面から反映面に向けてスポット光を透過させた透過像を直接デジ タルカメラで撮影, あるいはスクリーン上に映し出させる. 透過光の広がりを計測して, その広がりから加工表 面の粗さを推定する方法である.すなわち，(1)回折法を利用した粗さ測定，(2)散乱法を利用した粗さ測定につい て報告する. また, 加工面形状により透過像のパターンが異なるので, その透過像パターンから加工面形状が推 定できることも示寸.

\section{2. 測定原理}

\section{$2 \cdot 1$ 回折光を利用した表面粗さの測定}

透明体に入射した光は，その反映面で反射，屈折が起こり，さまざまな方向に散乱する．図 1 には，反映面の 凹凸ピッチとその高さが一定の場合の光の屈折を模式的に示した. 透明体の反映面に入射角 $\alpha$ で入射した光は, 空気中に屈折角 $\beta$ で透過すると寸る. 透過光は, 透明体表面から距離 $L$ のところにあるスクリーン上に回折スポ ットとして現れるので，スポット間の距離 $2 S$ を計測することができる.

材料表面に生じた凹凸のピッチを $P$ ，そのときの粗さを $R$ とすると

$$
\tan (\pi / 2-\alpha)=R \cdot P / 2
$$

ここで， $\lambda$ をレーザの波長とし， $P=\lambda \cdot L / S$ であり， $L \gg R$ より，式(2)が得られる.

$$
\tan (\beta-\alpha) \approx S / L
$$

また，透明体の屈折率を $n$ としたときのスネルの法則， $\sin \beta=n \sin \alpha$ より

$$
\beta=\sin ^{-1}(n \sin \alpha)
$$

式(2)と式(3)より， $\alpha$ と $\beta$ を求め, これらの結果を式(1)に代入することにより, 表面粗さ $R$ が求められる.

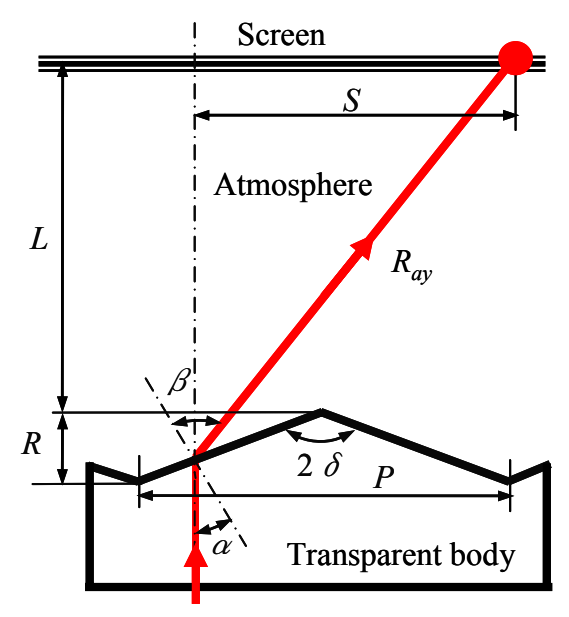

Fig.1 Diffraction of light 


\section{$2 \cdot 2$ 散乱光を利用した表面粗さの測定}

反映面の凹凸ピッチがランダムで，その高低が異なるとき，反映面からの散乱光は広がるので，その面積や範 囲は大きくなる. その広がりを, 図 2 に示すような 2 次元平面上の閉曲線の周長 $L$ で囲まれたパターンの面積 $A$ を考え, 面積と特徽的な長さ $L_{c}$ との間には式(4)の関係 ${ }^{(12)}$ が生じる.

$$
A \propto L_{c}{ }^{2}
$$

一つのパターンが成長する場合や，同じ要素から成る多くのパターンが共存している場合，フラクタル次元に 関連する回転半径法はそれらのパターンの平均的な広がり度合いを算出することができる. $N$ 個の構成要素から なるパターンについて, $i$ 番目の構成要素の位置を $r_{i}(I=1,2, \cdots, N)$ とすると, このパターンでスケーリングさ れる特徵的な長さ，すなわち回転半径 $R_{g}$ は

$$
R_{g}=\sqrt{\frac{1}{N} \sum_{i=1}^{N}\left(r_{i}-\bar{r}\right)^{2}}
$$

ただし， $\bar{r}$ はパターンの重心とし，式(6)に示される.

$$
\bar{r}=\frac{1}{N} \sum_{i=1}^{N} r_{i}
$$

ここで，パターンの重心を原点とすると， $\bar{r}=0$ となる.

回転半径 $R_{g}$ に含まれるパターンの構成要素のフラクタル次元 $D$ は

$$
N \cong R_{g}{ }^{D}
$$

の関係が成立する．スクリーン上に写し出される輝点の総和は面積 $A$ になるので， $D=2$ である. したがって， 求める回転半径 $R_{g}$ は

$$
R_{g}=\sqrt{A / \pi}
$$

一方, 散乱分布が長径 $a$, 短径 $b$ をもつ楕円形状の場合, 幾何平均としての回転半径 $R_{g}$ は

$$
R_{g}=\sqrt{a \cdot b}
$$

スクリーン上に照射される透過光が円形でも，楕円形でも，回転半径として表される，表面粗さが大きくなる ほど, 透過像の濃淡は変わり, その散乱分布の裙野も広がるので, 式(8), あるいは式(9)の回転半径 $R_{g}$ と粗さ $R_{z}$

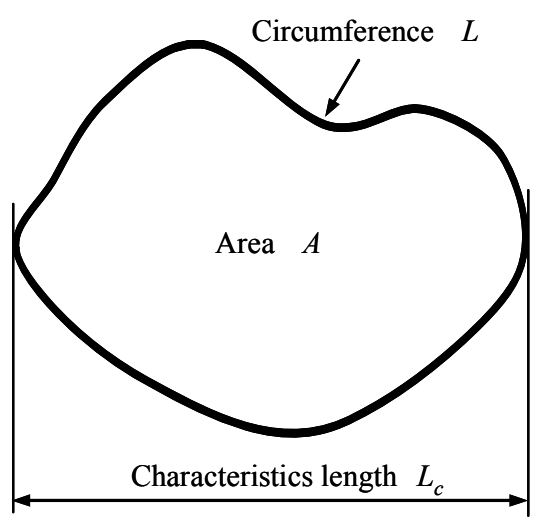

Fig.2 Characteristic length of patterns 
との関係を式(10)のように示すことができる.

$$
R_{z}=a \cdot R_{g}^{2}+b \cdot R_{g}+c
$$

ここで，定数 $a ， b$, および $c$ は，実験式より得られる.

\section{3. 実験方法}

\section{$3 \cdot 1 \quad$ レプリカ試験片の作製}

ラップ仕上げ，放電加工，研削，形削りなどの加工法で製作された比較用表面粗さ標準片は，粗さが異なる数 種類の凹凸面から作られている，それらの加工面が転写できるように，2 液混合の透明液状シリコーンゴム（透 過率 $97 \%$, 屈折率 $n=1.4 ）$ を加工表面に流し込み，真空チャンバーで脱泡処理して固化させ，レプリカを作製す る. 透明シリコーンゴムのレプリカは, 厚さ $20 \mathrm{~mm}$ の平板形状であり, 平板の加工面を転写した面が反映面, 反 映面と反対に位置する面が背面となる，比較用表面粗さ標準片と作製したレプリカを図 3 に示す．また，研削加 工面（最大高さ粗さ $R_{z}=3.2 \mu \mathrm{m}$ ）とそのレプリカの反映面の写真を図 4 示す．図4(a)の加工面には，規則正しい縦 方向の研削痕が見られる. (b)に示すレプリカ反映面の凹凸や形状は, (a)の研削面のそれらとは左右対称の位置に あり，複製を再現している．なお，使用したシリコーンゴムは，流動性に優れ，常圧・常温でも微細な隙間に容 易に流れ込み，かつ内部歪が生じ難い部材でもあるので，金属の加工表面の凹凸を正確に再現できる.

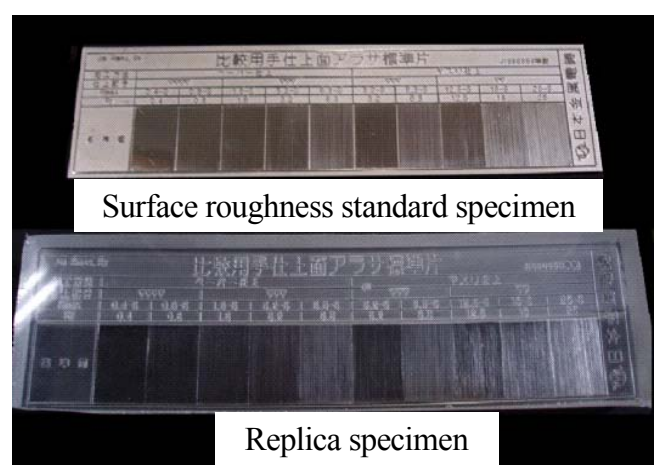

Fig.3 Surface roughness standard specimen for the comparison and the replica specimen
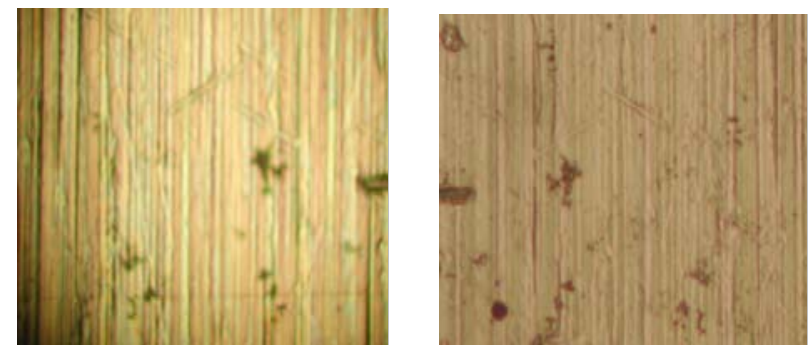

(a) Surface roughness standard specimen $\quad$ (b) Replica specimen

Fig.4 Surface roughness standard specimen for the comparison and the replica specimen

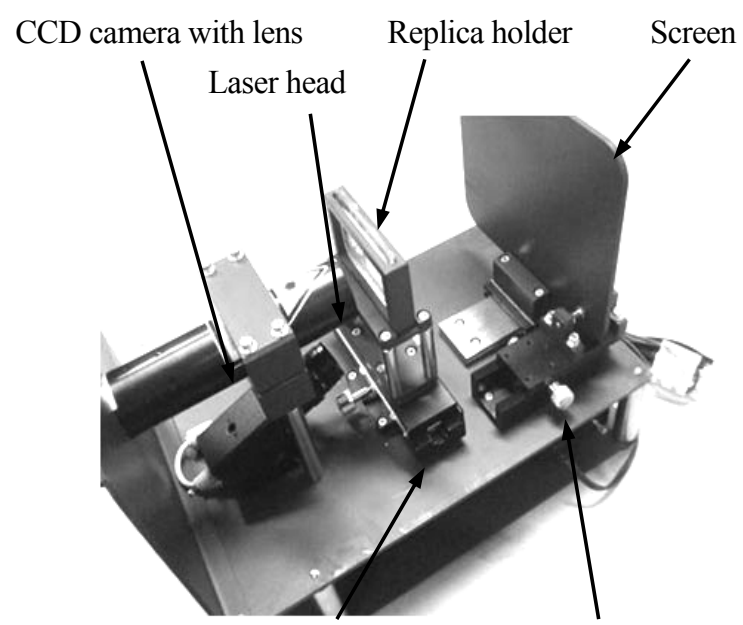

Replica holder slide $\quad$ Screen slide mechanism

Fig.5 Roughness equipment of worked surface 


\section{$3 \cdot 2$ 実験方法および実験装置}

本実験に用いた試作装置を図 5 に示す. 装置は, 加工表面の状態を反映する反映面を有するレプリカに対し, 反映面とは反対の面にあたる背面から反映面に向けて垂直に He-Ne レーザ光源（波長 : $635 \mathrm{~nm}$ ) を照射する光源， レプリカを透過した透過光を受光面で受光するスクリーン, 受光面において透過光の広がり範囲を撮影する CCD カメラより構成されている. なお，本装置には外蓋があり，周囲からの外乱光が遮断できるので，いかなる環境 下でも測定が可能である. 反映面とスクリーン間距離 $L$ は $300 \mathrm{~mm}$ とし, カメラの位置やシャッタースピード, 倍 率を固定して撮影した。 ここで，レプリカ反映面は，その反映面とほぼ同じ表面粗さを示寸 5 箇所を選定した. また，透過像は代表的な像を表示した．なお，表面粗さは，触針式表面粗さ測定器（ミツトヨ製サーフテスト） を用いて，加工表面の切削方向あるいは研削方向に対して直角方向に触針を移動させて測定した.

\section{4. 実験結果}

均一なスポット光を有するレーザ光は, レプリカ反映面で拡散あるいは一部が散乱する透過光を生成し，それ らの光が重㸚合わされてスクリーン上で結像する. この像を 4 つのパターンに分類した.

\section{$4 \cdot 1$ ポイントパターン}

ラップ仕上げによる加工表面の写真, 粗さ曲線, その加工面のレプリカ反映面に光線を照射してスクリーンに 映し出された透過像, および濃度物体画素数を図 6 に示寸. 図6(a)に示寸加工面はほぼ平坦で, 粗さのある凸凹 が見られない. (b)に示寸加工面の表面粗さ曲線はほぼ一定である. (c)のレプリカよりスクリーンに映し出された 透過像はその中心が明るく，その透過像と輝度は，レプリカのないポイント光のそれらとほとんど変わらないポ イントパターンであった. これは, 加工面の表面粗さの值が小さいので, レプリカ反映面を透過した後のポイント 光はほとんど散乱が起こらずに，スクリーンに出射されたと考えられる. (d)の濃度物体画素数の分布図の縦軸は 濃度物体の画素数を示し, 横軸は図(c)の光点を含む水平方向の長さで全長 $60 \mathrm{~mm}$ とした. なお，その分布図にお ける中央部の飽和は, デジタル画像の白黒の濃淡を 256 階調に起き換えたときの白部分の画素数を示し, 波形の 底辺は黒色を示す. (d)の濃度物体画素数は, 中央部がパルス状に現われる収差のない点像の光量分布になってい る.

\section{$4 \cdot 2$ 円形パターン}

図 7 には, 放電加工による加工表面の写真, 粗さ曲線, レプリカ反映面からの透過光パターン, 濃度物体画素 数分布を示寸. 放電加工は加工材料を溶融して, その部分を除去する加工方法であるので，(a)に示す加工面は, 高低のある凹凸で, 山部や谷部がなだらかで, 輪郭が不規則である放電痕が見られる. (b)に示寸粗さ曲線では, 大小の山部と谷部が現われ，ピッチもばらついている，(c)の透過光パターンは円形状で，中央部が明るく，そこ

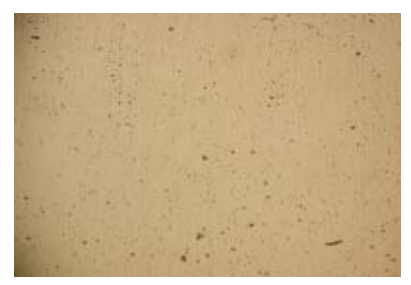

(a) Surface machined

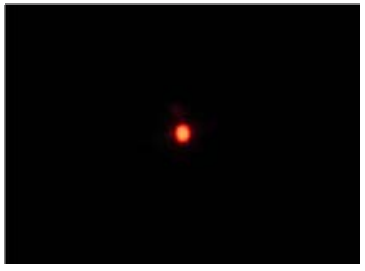

(c) Transmission image

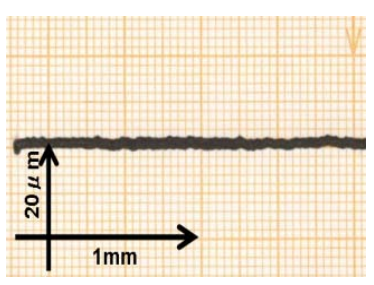

(b) Surface roughness

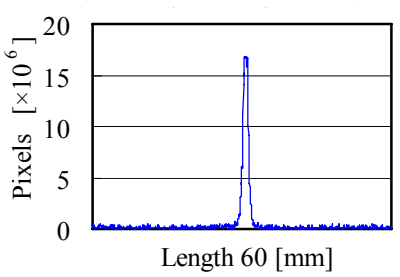

(d) Light intensity distribution

Fig.6 Lap processing 
から離れるにしたがって暗くなる. 受光パターンは縦方向あるいは横方向の一方向に延びることはなく，(d)のよ うな放射状に散乱されていて，ガウス分布に近い濃度物体画素数を示す．また，加工表面が粗くなるにしたがっ て, 受光部の中央部の高さは低くなり, 裙野が広がる傾向がある. なお, レーザ光は干渉性が非常に強いために, 反映面からの透過光はランダムな干渉により粒状性を帯びた斑点模様のスペックルパターンが現れている.

\section{$4 \cdot 3$ 楕円形パターン}

図 8 には，研削による測定結果を示す（a)に示寸加工表面は切削方向が一方向のスジ状の溝がランダムに切削 されている. (b)に示す粗さ曲線は, 大小の凹凸，角の立つ山部と谷部，不規則な輪郭が示されているので，(c)の 透過像は水平方向に長く伸び，垂直方向にわずかに広がる楕円形パターンになっている．この原因としては，レ プリカ反映面の凹凸は切削方向あるいは研削方向に対して垂直方向に転写されていて，その山部と谷部の高低が 異なり, ピッチや輪郭も不規則であることにより, 透過像は主に水平方向に広がる. 山部と谷部の加工方向がわ ずかにずれるため, 透過像が垂直方向にも広がる. また, 加工面の表面粗さが粗くなるにつれて, 透過像が広が ることも確認できた. なお, 透過光の濃度物体画素数(d)は, 中央部の濃度分布が高く, 水平方向になだらかに低 くなっている.

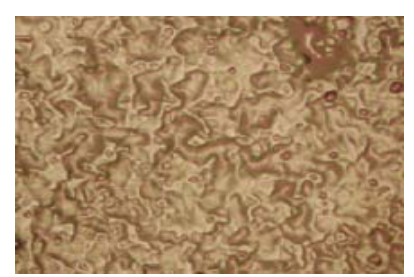

(a) Surface machined

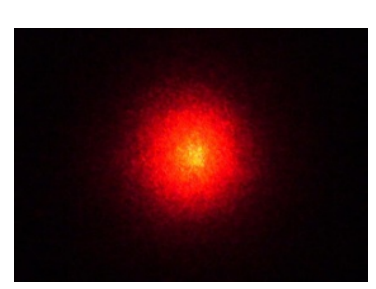

(c) Transmission image

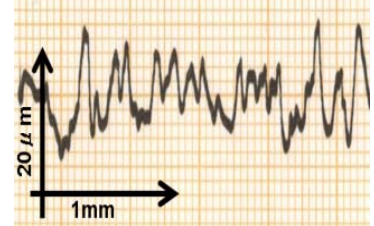

(b) Surface roughness

Fig.7 Electric discharge machining

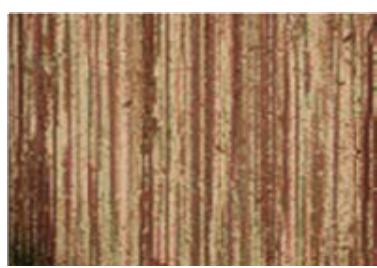

(a) Surface machined

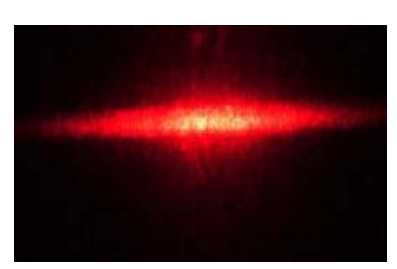

(c) Transmission image

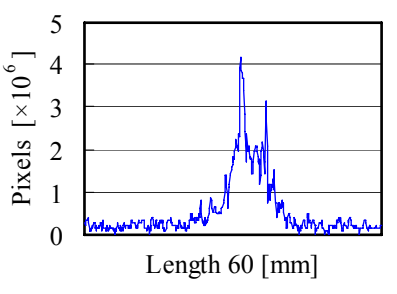

(d) Light intensity distribution

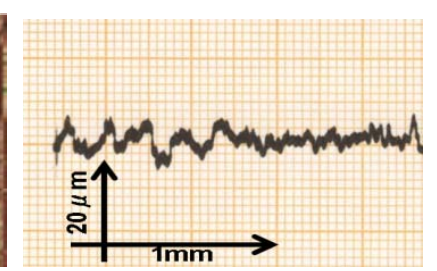

(b) Surface roughness

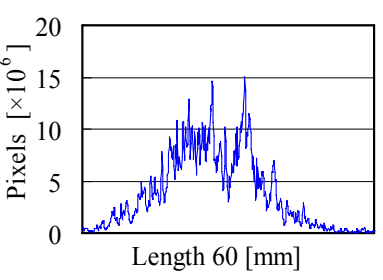

(d) Light intensity distribution

Fig.8 Grinding 


\section{$4 \cdot 4$ 回折パターン}

形削り加工は工具の直線切削運動と工作物の直線送り運動との組合せによる加工方法のため, 図 9(a)に示す切 削加工面，および(b)の粗さ曲線は，輪郭は規則正しく，山の高さとピッチもそろっている断面形状をもつ. (c)の 透過光は，回折現象が現われていて，形削り方向に対して直角方向に伸びているのが分かる．特に両端の輝点が 最も明るく，その間に小さな輝点が数箇所に一列に並んでいる．これは，規則正しく加工されている加工斜面で 光の回折が起き，その透過光がスクリーン上に現れたためである. また，溝の間隔が狭いと輝点の間隔は広くな る. 一方, 溝間隔が長くなると, 輝点は間隔が狭くなり, 連続性を帯び, 一つの光の固まりになる. (d)に示寸濃 度物体画素数は両端部で 0 次光を示し, 中央部に進むにつれて光強度が弱くなっている. 反映面からの光は光路 差による回折と干渉によって, スクリーン上に 0 次， 1 次， 2 次， $\cdots, n$ 次の明暗の縞を作り，光源からの直接 光は 0 次光で最も明るく, 続いて 1 次光, 2 次光の順に暗くなる. なお, 明るさの異なる点の規則正しい並びは, 凹凸の長短周期に依存すると考える.

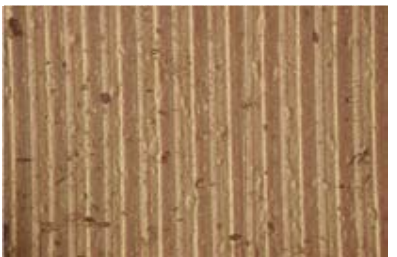

(a) Surface machined

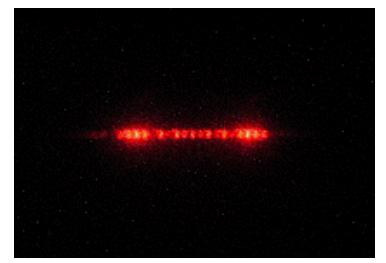

(c) Transmission image

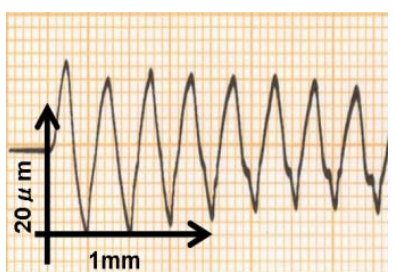

(b) Surface roughness

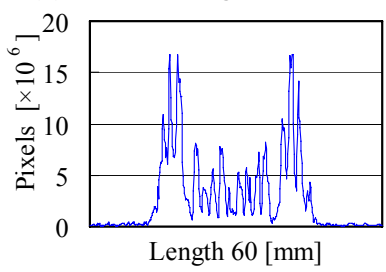

(d) Light intensity distribution

Fig.9 Shaping processing.

\section{5. 考察}

\section{$5 \cdot 1$ 回折光による加工面粗さの測定}

図 9 に示したように, 形削り加工面が縦方向に溝を有する場合, そのレプリカ反映面を透過する光は, 反映面 の溝の方向と直交する方向に回折光が生成される.このことは，反映面を透過した光の受光面において輝点の間 隔の大小に基づいて，加工表面の粗さの判定ができることを意味する.

形削り加工のレプリカ反映面からの回折光は, 式(1)〜(3)を用いて計算された表面粗さの測定結果と触針式粗さ 測定装置によって求めた最大高さ粗さとの関係を図 10 に示した. 計測データは 5 回行い, それらの測定值は縦線 の範囲で示した．回折光による表面粗さと最大高さ粗さには比例関係があり, 高い精度で表面粗さが求められて いる. なお，凹凸のピッチ $P$ は，試験片表面より求めた。 また，形削り加工面は規則的な三角形状の凹凸をもつ ので, 形削り面のレプリカ反映面における光の回折は, その山頂や谷間で現われるのでなく, その斜面で発生す る. このため, 反映面の斜面が粗さに関連する表示法は, 算術平均粗さよりも最大高さ粗さが適していると考え, 最大高さ粗さを採用した。 なお, 本実験で用いた加工面は三角形であるので, 最大高さ粗さの約 $1 / 4$ が算術平均 粗さである.

\section{$5 \cdot 2$ 散乱光による加工面粗さの測定}

反射光強度分布を二次元ガウス関数の直交する標準偏差を用いて表面粗さを表示する方法(6)がある. ここでは, 直交 2 方向の評価ではなく, $360^{\circ}$ 方向の粗さを測定できる方法について提案する. 図 11 には, デジタル画像(a) とモノクロ画像(b)を示寸，モノクロ画像は，デジタル画像をモノクロ化，シェーディングの補正，ノイズを除去 した後に，5つの基準値，すなわち閾値を設けて，6 階調の濃淡画像に分割した。 これらの画像における濃度物体 
画素数の分布は，散乱が小さいとパターンの中心部の周りに集中するが，散乱が大きくなるとその中心部が減少 して裙広がりになる．したがって，透過光がどの範囲にどのように分布しているかは，モノクロ画像を階調化す ることにより明らかにできる，なお，デジタル画像にはスペックルパターンが現れているが，6 階調のモノクロ 画像に変換するとスペックルパターンは除去できる.

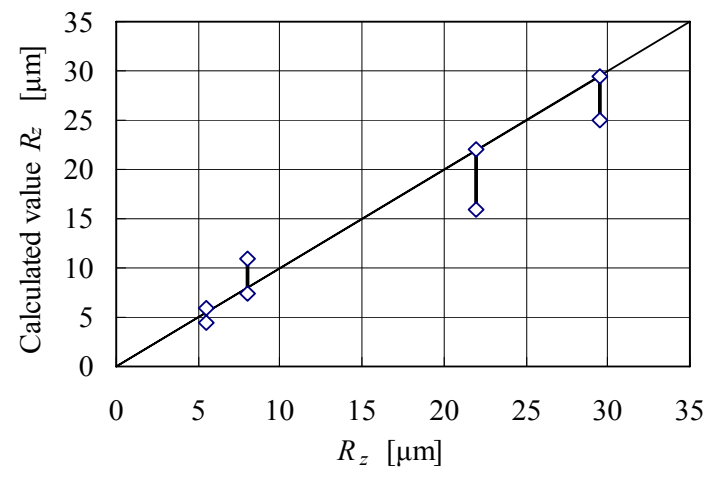

Fig.10 Relationship between calculated value and $R_{z}$

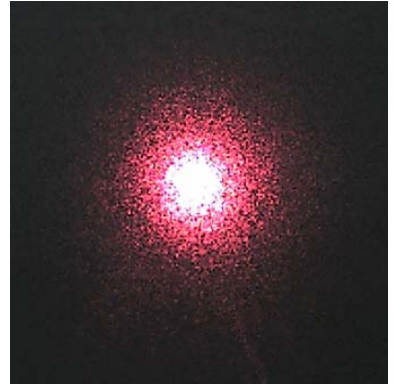

(a) Digital image

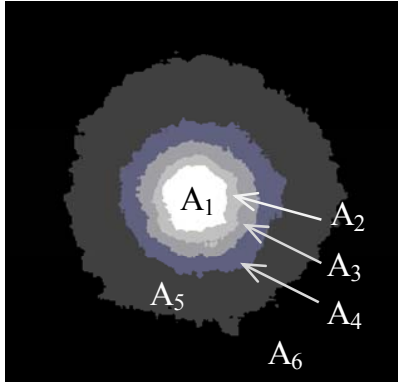

(b) Gray scale

Fig.11 Digital image obtained from electric discharge machining

図 12 には, 放電加工による円形パターンの回転半径 $R_{g}$ と最大高さ粗さ $R_{z}$ との関係を示す. 階調 $\mathrm{A}_{1}$ と $\mathrm{A}_{2}$ にお いて, $R_{z}=10 \mu \mathrm{m}$ までは $R_{g}$ は $R_{z}$ とともに増加しているが， $R_{z}$ がさらに大きくなると $R_{g}$ は逆に小さくなる．階調 $\mathrm{A}_{3}$ と $\mathrm{A}_{4}$ では, $R_{a} \fallingdotseq 18 \mu \mathrm{m}$ までは $R_{g}$ は増加するが, その後 $R_{z}$ は増加しても $R_{g}$ は一定である. 階調 $\mathrm{A}_{5}$ において, $R_{g}$ は粗さが 5 30 $\mu \mathrm{m}$ までは $R_{z}$ の増加とともに増加しているので, 階調 $\mathrm{A}_{5}$ を用いると, 広範囲の粗さを求めるこ とができる. 回転半径 55 92 $\mathrm{mm}$ の範囲において, 回転半径と表面粗さとの実験式を求めると, 次式が得られた.

$$
R_{z}=0.0265 \cdot R_{g}^{2}-3.0483 \cdot R_{g}+90
$$

式(11)を用いれば, 円形パターンの回転半径 $R_{g}$ から表面粗さ $R_{z}$ が得られる.

次に, 図 13 には, 研削加工による楕円形パターンの回転半径 $R_{g}$ と最大高さ粗さ $R_{z}$ との関係を示寸．階調 $\mathrm{A}_{1}$ $\sim \mathrm{A}_{5}$ において, $R_{z}=4 \sim 13 \mu \mathrm{m}$ の範囲では $R_{g}$ は $R_{z}$ の増加とともに緩やかに増加していて, その傾きは階調が大き くなるほど小さくなっている. これは, 表面粗さが大きくなると, 散乱光は広がるためである. 回転半径 $R_{g}$ と粗 さ $R_{z}$ の関係は比例関係が望ましいので，ここでは，広範囲の粗さを求めることができる階調 $\mathrm{A}_{5}$ を採用する．こ の結果, 階調 $\mathrm{A}_{5}$ による楕円形パターンの回転半径と表面粗さ $R_{z}$ との実験式を求めると, 回転半径 $28 \sim 48 \mathrm{~mm} の$ 範囲では，式(12)が得られた。式(12)の実験式を用いれば，楕円形パターンの幾何平均の $R_{g}$ から表面粗さが得ら れる.

$$
R_{z}=0.0113 R_{g}^{2}-0.8233 R_{g}+6
$$


以上のことから，本解析法は，レプリカ反映面の凹凸をスクリーン平面上での透過光の広がりや強弱を有する 円形パターンと楕円形パターンで示し, それらを回転半径に置き換えて回転半径と粗さとの実験式を求めた。 こ れは，加工方向に影響を受けない $360^{\circ}$ 方向の平均粗さを求める評価方法である. しかし，ポイントパターンで は，散乱光が現われないので，表面粗さが求められない.

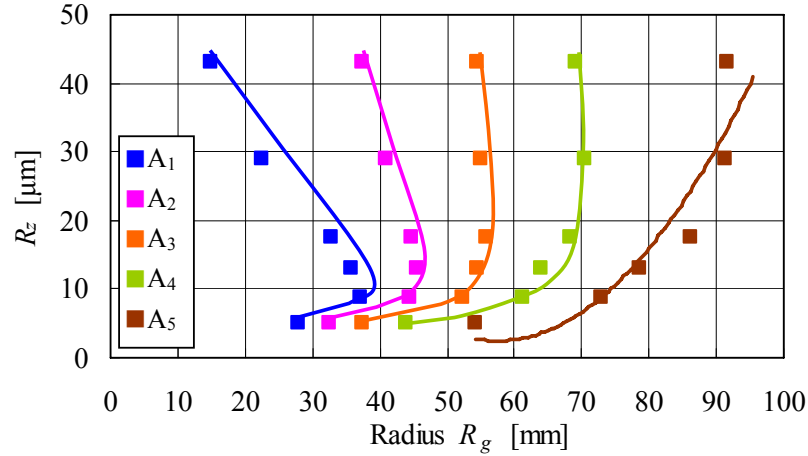

Fig.12 Relationship between radius of revolution $R_{g}$ and maximum height roughness $R_{z}$ for electric discharge machining.

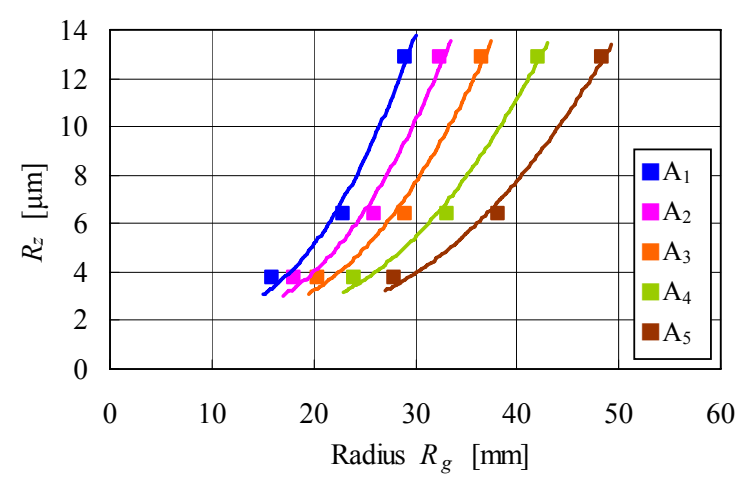

Fig.13 Relationship between radius of revolution $R_{g}$ and maximum height roughness $R_{z}$ for grinding

本測定法の粗さの範囲は，ミクロンから数百ミクロンの表面凹凸の評価が可能であり，測定面積をもつ表面形 態に敏感であるので，新たな表面粗さパラメータの創出の可能性があり，従来の触針や光測定法を補完する第三 の粗さ評価法と考える. 測定対象物は金属のような硬い物質を含め, 皮膚や食品等の柔軟物表面 ${ }^{(13)}$ 一の適用も可 能であり，さらには装置は簡易に組み立てられ，かつ安価であり，レプリカもデスポーザルに利用できる簡便・ 安全な部品である。

\section{6. 結 言}

透明シリコーンを用いて金属加工表面のレプリカを作製し，スポット光をレプリカ反映面に透過させ，透過像 を調べる新しい測定法を提案した。得られた結果を以下に要約する.

(1) レプリカ反映面から透過像は，ポイント，円形，楕円形，回折の 4 つのパターンに分類できる.

(2) これらのパターンは反映面の表面状態, 寸なわち加工面の表面形状や加工方法を推定することができる.

(3) 回折パターンは, 計算值より最大高さ粗さを表すことができる. 円形パターンと楕円形パターンでは, 回転 半径と最大高さ粗さの関係を示す実験式が得られた.

(4) ポイントパターンは，本実験の測定範囲では表面粗さを表すことができなかった.

(5) 本測定法は， $R_{z}=5 \mu \mathrm{m} \sim 40 \mu \mathrm{m}$ の表面凹凸の評価が可能であり，測定面積をもつ表面形態に敏感である.

(6) 本装置は簡易に組み立てられ, かつ安価であり, レプリカもデスポーザルに利用できる簡便・安全な部品 である。

\section{文献}

(1) 齋藤明徳, 堤 正臣, 黄 錦鐘, “仕上げ面の断面曲線による工作機械の性能評価”, 日本機械学会論文集 C 編, Vol.58, No.545(1992), pp.277-282.

(2) ISO25178-601, “Geometrical Product Specifcations(GPS)-Surface Texture:Areal-Part601 : Norminal Characteristics of Contact(Stylus) Instrument".

(3) Tanner, L.H., "The use of laser light in the study of metal surfaces" ,Optics and Laser Technology, Vol.8, No.3(1976), pp.113-116.

(4) 栗田正則, 佐藤 誠, 中島一馬, “レーザによる表面粗さの迅速な測定法”，日本機械学会論文集 A 編，Vol.56， No.532(1990), pp.2588-2592. 
（5）深谷次助，佐々木彰，岩田 太，田口敬之，橋本保幸，山中崇志慶，“シングルスリットを用いた鏡面反射率によ る表面粗さ測定の研究”, 精密工学会誌, Vol.75, No.11(2009), pp.1305-1309.

(6) 栗田正則, 鄧 智 聡, “散乱光を用いた直交二方向の光学的表面粗さ測定法”, 日本機械学会論文集 C 編, Vol.63-605(1997-1), pp.254-261.

（7）小田 功, 佐々木拓哉, “縞パターンの投影による透明体および半透明体の表面性状の評価法”, 精密工学会誌, Vol.76, 5(2010), pp.529-534.

（8）秋山伸幸, 吉田昌弘, 栗田正則, 鄧 智 聡, “鋳物表面粗さ光学式測定における測定精度向上法”, 精密工学会誌, Vol.65, No.12(1999), pp.1756-1760.

（9）日本鉄鋼協会特定基礎研究会，“而熱鋼の高温クリープ及びクリープ疲労損傷材のレプリカ法による非破壊的損傷 量/寿命評価”, 日本鉄鋼協会(1991).

(10) 長谷川幸平，“表面粗さ計測方法”，公開特許 JP1988-191010(1988).

(11) 横田＼cjkstart理，“加工表面評価装置”，特許 JP4845003(2011), (平成 23 年 10 月 21 日).

(12) 松下 貢, “フラクタルの物理( I )基礎編”, 裳華房, pp.21-47(2002).

(13) 長尾光雄, 横田 理, 依田満夫, “柔らかさおよび粘弾性を計測できる機能性試験機の開発”, 日本機械学会論文集 C 編, Vol.76, No.770(2010), 2598-2603. 